\title{
TOTAL PHENOLIC, ANTHOCYANINS AND TBA-ACTIVE PRODUCTS IN BUCKWHEAT PLANTS UNDER NaCI IMPACT
}

\author{
I. V. Derkach ${ }^{\star 1}$, S. Timmusk ${ }^{2}$, N. D., Romanyuk ${ }^{1}$ \\ ${ }^{1}$ Ivan Franko National University of Lviv, 4, Hrushevskyi St., Lviv 79005, Ukraine \\ ${ }^{2}$ Uppsala Biocenter, SLU, P.O. Box 7026, SE-75007, Uppsala, Sweden \\ *e-mail: ari9456@gmail.com
}

Derkach I. V., Timmusk S., Romanyuk N. D. Total phenolic, anthocyanins and TBA-active products in buckwheat plants under $\mathrm{NaCl}$ impact. Studia Biologica, 2018: 12(3-4); 27-34 - DOI: https://doi.org/10.30970/sbi.1203.550

High salt concentration in soils cause osmotic and ionic stress for plants, along with oxidative stress and inhibition of growth and development, as a consequence, reducing the yield of many crops important for agriculture. Buckwheat (Fagopyrum esculentum Moench.) is classified as a salt-sensitive glycophyte plant, but salt tolerance of this culture is higher among many important food crops. The salt impact on the total levels of phenolics, anthocyanins and TBA-active products as the oxidative lipid peroxidation parameter, was determined in buckwheat plants (cv. Ukrainka) on $48,72 \mathrm{~h}$ and $7^{\text {th }}$ days of high $\mathrm{NaCl}$ exposure. Plants were grown on the $1 / 2$ Hoagland-Arnon's nutrient solution with/without addition of $100 \mathrm{mM} \mathrm{NaCl}$. After $72 \mathrm{~h}$ of salt exposure, the TBA-active products increased in leaves and stems (130 and $204 \%$, respectively). Maximum of the TBA-active products was noticed at $72^{\text {nd }} \mathrm{h}$, particularly in stems. On the $7^{\text {th }}$ day of salt stress, the TBA-active products level decreased in leaves and roots, while in stems it remained at high level. Total amount of the phenolic compounds in the buckwheat roots treated with $\mathrm{NaCl}$ ranged from 35.55 to $64.95 \mu \mathrm{g} / \mathrm{g}$ DW in leaves - from 98.36 to $112.49 \mu \mathrm{g} / \mathrm{g} \mathrm{DW}$ at different time points. In stems, the amount of total phenolic compounds was at the level in between 80.71 to $108.32 \mu \mathrm{g} / \mathrm{g} \mathrm{DW}$. After $48 \mathrm{~h}$ of $\mathrm{NaCl}$ impact, the total phenolic level decreased by 51 and $26 \%$ in the roots and leaves, respectively. The same tendency was observed on the $3^{\text {rd }}$ day of the experiment. Finally, on the $7^{\text {th }}$ day the total phenolic content in roots approximated to the control level, however in leaves it was lower and in stems higher than in control. Content of the phenolic compounds was significantly higher in the above ground parts. An increase of the anthocyanin content during the long-term exposure to the stress was consistent with the statement regarding their secondary response to overcome an oxidative stress. Salt shock adversely affected physiological activity of the buckwheat

(C) 2018 I. V. Derkach et al.; Published by the Ivan Franko National University of Lviv on behalf of Біологічні Студії / Studia Biologica. This is an Open Access article distributed under the terms of the Creative Commons Attribution License (http://www.budapestopenaccessinitiative.org/ and Creative Commons Attribution 4.0 License), which permits unrestricted reuse, distribution, and reproduction in any medium, provided the original work is properly cited.

ISSN 1996-4536 (print) • ISSN 2311-0783 (on-line) • Біологічні Студії / Studia Biologica • 2018 • Том 12/№3-4 • C. $27-34$ 
plants whereas a decrease of the TBA-active products, and a restoring of phenolics quantity in plant organs under prolonged salt stress points to an activated adaptive response.

Keywords: buckwheat, $\mathrm{NaCl}$, phenolic compounds, anthocyanins, TBA-active products

\section{INTRODUCTION}

High salt concentration in the produce osmotic and ionic stresses, oxidative stress and inhibition of plants growth and development, and, as consequence, reduce yield of many important crop cultures $[4 ; 11 ; 12 ; 21]$. Salinity with the increase of arid and semiarid areas becomes one of the global problems for food security and agriculture. Studying and creating of salt-tolerant varieties are important for the future decades. The priority is getting a better understanding of salt responses at molecular, cellular, and whole plant levels [2; 4; 16; 21]. Buckwheat (Fagopyrum esculentum Moench.) is classified as a salt-sensitive glycophyte plant, but its' salt tolerance is higher if compare with many important crops [9; 26]. Nowadays, buckwheat becomes an important alternative source for human nutrition, because of its high nutrient value, possibility to use for health care, and high developmental potential $[5 ; 12 ; 13 ; 19 ; 20 ; 25]$. Usage of $F$. esculentum as a functional food largely benefits from the abundance of phenolic compounds with high antioxidant properties $[6 ; 8 ; 12 ; 29]$. On the other hand, high level of antioxidants, including anthocyanins, in plant tissues is one of the possible mechanisms of buckwheat ability to cope with salinity stress [20;25]. A majority of current, published results is devoted to salt effects on phytochemicals in buckwheat sprouts or grains [13]. It was reported that the sprouts of common buckwheat contain an abundance of flavonoids, including C-glycosyl flavones (orientin, vitexin, and their isomers) and rutin, while tartary buckwheat contain only high concentration of rutin [25, 13; 14]. Recent studies demonstrated that 385 genes are differentially expressed under $100 \mathrm{mM} \mathrm{NaCl}$ stress [15]. There are also metabolic data on phenolic compounds under other stress conditions in F. esculentum and its relative Fagopyrum tataricum (L.) Gaertn. (tartary buckwheat) $[6 ; 8 ; 9 ; 17 ; 23]$. However, there are no data on phenolic compounds concentrations as antioxidant substances and salt response to the level of whole plant on early stages of growth, which are critical for further development and yield. Thus, the aim of present work was to determine levels of total phenolic compounds and anthocyanins in different organs of $F$. esculentum in connection with the lipid peroxidation processes on the $48^{\text {th }}, 72^{\text {nd }} \mathrm{h}$ and 7 days of $100 \mathrm{mM} \mathrm{NaCl}$ influence.

\section{MATERIALS AND METHODS}

Plant material and growth conditions. The object of investigations were 14 days buckwheat plants (Fagopyrum esculentum Moench) cv. Ukrainka. Seeds were pre-germinated for 3 days at $22 \pm 1^{\circ} \mathrm{C}$ in the darkness. Uniform seedlings were transferred into pots with perlite as substrate for further growth in the greenhouse under controlled conditions with $16 \mathrm{~h}$ photoperiod and $22 \pm 1^{\circ} \mathrm{C}$ temperature. Seedlings were irrigated by a $1 / 2 \mathrm{Hoa}-$ gland-Arnon's nutrient solution. After two weeks of growth (period when biomass accumulated), $100 \mathrm{mM} \mathrm{NaCl}$ was added to the part of plants as described [3]. The control set was grown with adding a $1 / 2$ Hoagland-Arnon's nutrient solution. Samples of roots, stems and leaves were collected on $48^{\text {th }}$ and $72^{\text {nd }} \mathrm{h}$ and on the $7^{\text {th }}$ day of salt treatment.

Lipid Peroxidation. The level of lipid peroxidation in cells of buckwheat leaves, stems and roots was measured as the amount of the TBA-active products (malondial-

ISSN 1996-4536 (print) • ISSN 2311-0783 (on-line) • Біологічні Студії / Studia Biologica • 2018 • Том 12/№3-4 • С. 27-34 
dehyde (MDA)) determined by the tiobarbituric acid reaction [16]. The absorbance of the supernatant was monitored at $532 \mathrm{~nm}$, subtracting the value for non-specific absorption at $600 \mathrm{~nm}$ spectrophotometrycally with SF-43. MDA content was calculated in nmol MDA per gram of dry weight (DW), and the level of lipid peroxidation was expressed in regarding to control (100\%).

Total phenolic compounds were quantified by the reaction with Folin-Ciocalteu reagent, absorbance was measured at 725-730 nm. Phenolic compounds were calculated with a calibration curve using chlorogenic acid as standard and expressed in $\mu \mathrm{g}$ per $\mathrm{g} \mathrm{DW}$.

Determination of anthocyanins content. Anthocyanins were extracted by the method of Jaleel et al. [7]. The absorbance was measured at $525 \mathrm{~nm}$ with the spectrophotometer (SF 43) against $\mathrm{HCl}$ : methanol (1:100 v/v) as a blank. Anthocyanin content was calculated as cyanidin-3-glucoside using 29,600 as a molecular extinction coefficient and 445 as a molecular weight. Three or four independent replicates were analyzed, for roots, stems and leaves, separately. The results were expressed in microgramms per gram of dry weight (DW).

Statistical analysis. All experiments were performed using four replicates. The results were analyzed statistically, the mean value $(M)$ and the standard error $( \pm m)$ were calculated using Microsoft Excel. Significance between control and treatment was compared at 0.05 probability levels using the Student's test.

\section{RESULTS AND DISCUSSION}

One of harmful effects of salinity is the overproduction of free radicals, which can cause protein denaturation, lipid peroxidation and cell membranes damage, etc $[14 ; 21$; $24 ; 28]$. Lipid peroxidation is often used as a marker of oxidative stress in biosystems $[2 ; 8 ; 13 ; 24]$. Short-term impact of salt led to a significant increase of the TBA-active products content in leaves and stem of buckwheat plants (Fig. 1). After $72 \mathrm{~h}$ of salt exposure, the level of TBA-active products increased in leaves and stems by 130 and $204 \%$, respectively. On the contrary, in the roots of experimental plants the decrease in TBA-

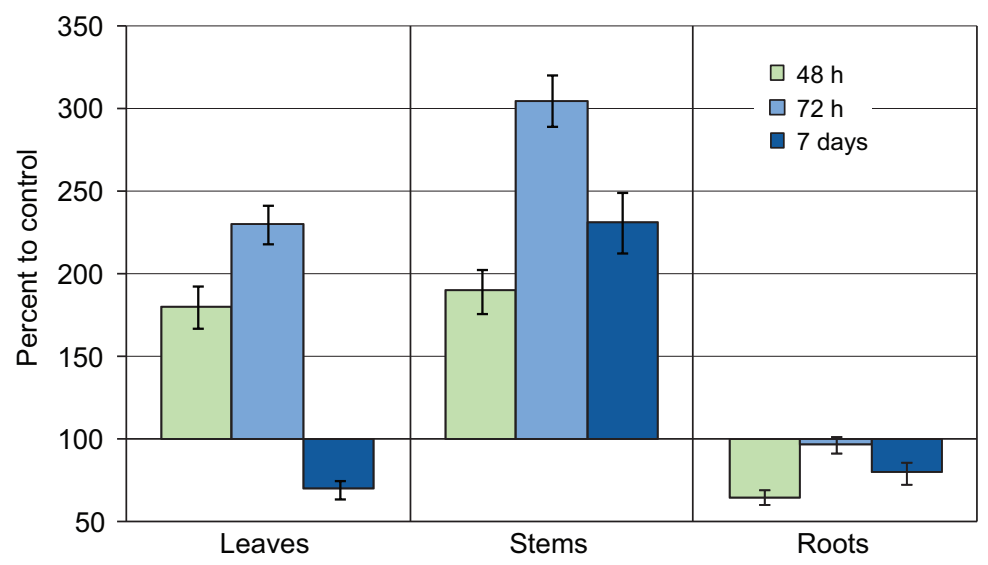

Fig. 1. Results of estimation of influence of $100 \mathrm{mM} \mathrm{NaCl}$ on the level of lipid peroxidation (TBA-active products formation) in F. esculentum (cv. Ukrainka) plants. Control - $1 / 2$ Hoagland-Arnon's nutrient solution

Рис. 1. Вплив $100 \mathrm{mM} \mathrm{NaCl}$ на рівень пероксидного окиснення ліпідів (за утворенням ТБК-активних продуктів) у рослин F. esculentum (с. Українка). Контроль - $1 / 2$ поживне середовище Хогланда-Арнона

ISSN 1996-4536 (print) • ISSN 2311-0783 (on-line) • Біологічні Студії / Studia Biologica • 2018 • Том 12/№3-4 • С. 27-34 
active products content was revealed. Generally, the maximum of TBA-active products were detected on the $72^{\text {nd }} \mathrm{h}$ of salt impact, especially in stems. On the $7^{\text {th }}$ day of salt stress, the content of TBA-active products decreased in leaves and roots, while in stems it remained at high level.

Thus, under the short term salt impact the level of the TBA-active compounds increased, inducing defence responses, which led to a decrease of this parameter on the $7^{\text {th }}$ day of salt stress. An oxidative stress activates an enzymatic and non-enzymatic antioxidant systems, including phenolics. Phenolic compounds and flavonoids play crucial roles in plants as growth regulators, cell wall components, and protective substances under the biotic and abiotic stress $[2 ; 4 ; 22 ; 27]$. To analyze a possible involvement in the salt responces, the level of the phenolic compounds and anthocyanins in buckwheat were determined.

Different distribution of phenolic compounds in plants organs with the significant predominance of their contents in leaves and stems, less extent in roots was revealed (Fig. 2). Total amount of the phenolic compounds in roots treated with $\mathrm{NaCl}$ ranged from 35.55 to $64.95 \mu \mathrm{g} / \mathrm{g}$ DW in leaves - from 98.36 to $112.49 \mu \mathrm{g} / \mathrm{g}$ DW at different time points. In stems, the amount of total phenolic compounds was at the level ranged from 80.71 to $108.32 \mu \mathrm{g} / \mathrm{g} \mathrm{DW}$. After $48 \mathrm{~h}$ of $\mathrm{NaCl}$ impact the total phenolic level decreased by 51 and $26 \%$ in the roots and leaves, respectively. This trend remained to a $3^{\text {rd }}$ day of the experiment. Finally, on the $7^{\text {th }}$ day of the $\mathrm{NaCl}$ impact, the total phenolic content in roots became close to the control level, in leaves it was lower and in stems higher than in control. Thus, we assume that the depletion of total phenolics pool points to their involvement on early salt responces of buckwheat and probably altered phenolics biosynthesis or changed direction of metabolic pathways. Some phenolic compounds serve as precursors for anthocyanins, that belong to a non-enzymatic ROS scavenging system and also involved in the salt stress responses of other plant species $[1 ; 4 ; 10$; $14 ; 21 ; 22 ; 24]$.

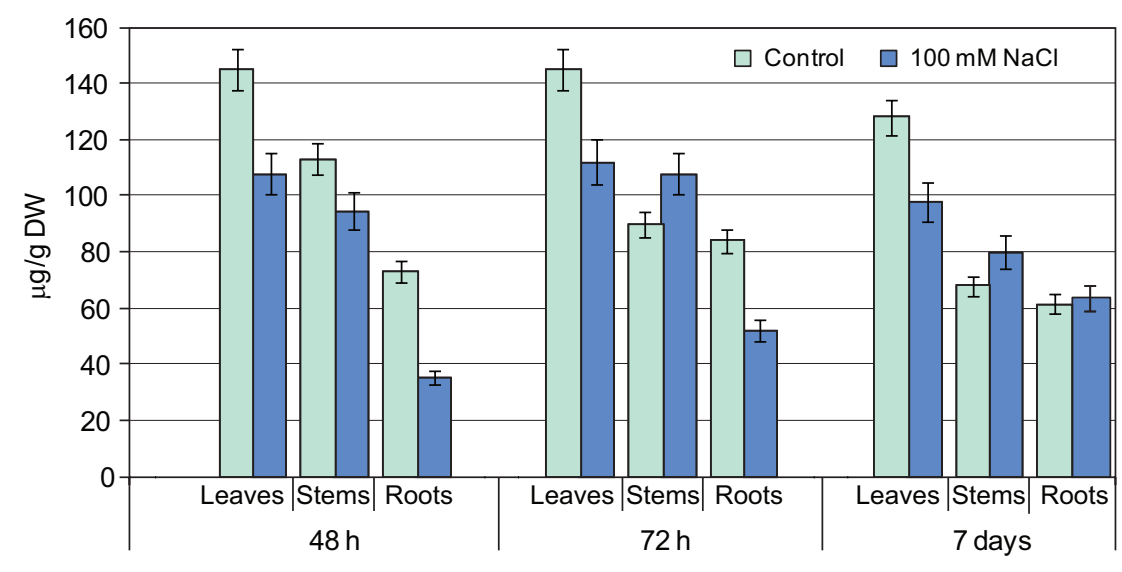

* - significant at $p \geq 0.95$

Fig. 2. Content of total phenolic compounds ( $\mu \mathrm{g} / \mathrm{g} D W$ ) in F. esculentum (cv. Ukrainka) leaves, stems and roots of 14-days old plants under the $48,72 \mathrm{~h}$ and 7 days of $\mathrm{NaCl}$ impact; control $-1 / 2$ HoaglandArnon's nutrient solution

Рис. 2. Загальний вміст френолів (мкг/г сухої речовини) у листках, стеблах і коренях 14-добових рослин F. esculentum (с. Українка) за 48, 72 год і 7 діб впливу $\mathrm{NaCl}$; контроль - 1/2 поживне середовище Хогланда-Арнона

ISSN 1996-4536 (print) • ISSN 2311-0783 (on-line) • Біологічні Студії / Studia Biologica • 2018 • Том 12/№3-4 • С. 27-34 
Differences in the total anthocyanins content in the buckwheat organs under salt influence are presented in Table. There were no significant changes in anthocyanins during the first 48-72 $\mathrm{h}$ of $\mathrm{NaCl}$ impact. However, on the $7^{\text {th }}$ day of salt stress, the anthocyanins content decreased by 59 and $55 \%$ in leaves and roots, respectively. In contrast, in stems was increased by $75 \%$. A decrease in the anthocyanins content in roots was detected on all time points of the salt influence.

An increase of TBA-active products concentration in leaves of $F$. esculentum caused by $\mathrm{NaCl}$ treatment was also reported by Ž. Jovanović et al. [9] with plants cultivated hydroponically on $1 / 2$ Murashige-Skoog nutrient solution. Salinity increased TBA-active compounds on the $2^{\text {nd }}$ and $7^{\text {th }}$ days of treatment, and elevated the level of TBK-active compounds was related to an increasing of ROS in early responses to the salinity.

The results of $\mathrm{H}$. J. Kim et al. (2008) on romaine lettuce demonstrated that 2 days salinity caused phenolic content decrement, whereas there were no significant differences under the long term (15 day) treatments [11]. Similar result with a reduction in total phenol and flavonoid in artichoke leaves under $\mathrm{NaCl}$ influence was obtained by A. Rezazadeh et al. [21].

\section{The results of measuring the impact of $100 \mathrm{mM} \mathrm{NaCl}$ on total anthocyanin content ( $\mu \mathrm{g} / \mathrm{g} \mathrm{DW})$ in $F$. esculentum (cv. Ukrainka) plants. Control $-1 / 2$ Hoagland-Arnon's nutrient solution}

Вплив 100 мM NaCl на загальний вміст антоціанів (мкг/г сухої речовини в рослинах F. esculentum (с. Українка). Контроль - 1/2 поживне середовище Хогланда-Арнона

\begin{tabular}{|c|c|c|c|c|c|c|}
\hline \multirow{2}{*}{$\begin{array}{c}\text { Time of } \\
\text { exposition }\end{array}$} & \multicolumn{3}{|c|}{ Control } & \multicolumn{3}{|c|}{$\mathrm{NaCl}$} \\
\hline & Leaves & Stems & Root & Leaves & Stems & Root \\
\hline 48 hours & $899.1 \pm 35.4$ & $871.0 \pm 134.6$ & $60.2 \pm 3.7$ & $887.2 \pm 48.0$ & $647.7 \pm 82.7 \downarrow$ & $40.8 \pm 7.3 \downarrow$ \\
\hline 72 hours & $869.4 \pm 51.5$ & $586.5 \pm 61.3$ & $163.5 \pm 14.5$ & $683.8 \pm 49.2$ & $520.41 \pm 30.25 \downarrow$ & $124.9 \pm 9.7 \downarrow$ \\
\hline 7 days & $1285.7 \pm 27.5$ & $449.9 \pm 22.2$ & $225.8 \pm 11.2$ & $1523.6 \pm 16.9^{* \uparrow}$ & $786.5 \pm 29.7^{* \uparrow}$ & $102.5 \pm 4.8^{*} \downarrow$ \\
\hline
\end{tabular}

* -significant at $p \geq 0.95$

However, these results are opposite to those reported by $\mathrm{H}$. J. Lim et al. [13] for leaves of $F$. esculentum under the effect of $10,50,100$, and $200 \mathrm{mM} \mathrm{NaCl}$. Accumulation of low molecular weight antioxidants, such as anthocyanins and phenolic compounds, in salt sensitive plants, may have multiple functions under stress conditions [4]. The total phenolic contents usually decrease in salt sensitive plants and increase in salt tolerant plants. Differences between the results of various studies are caused by analyzed organ (fruit, leaves, root), determination methods, values expression in terms of dry or fresh weight. A decrease in the phenolic compounds and anthocyanin concentrations in roots and leaves of the buckwheat under the short term impact of $100 \mathrm{mM} \mathrm{NaCl}$ suggests that they are involved in salt shock responses, but their pool is gradually depleted. The increase in the level of anthocyanins on the $7^{\text {th }}$ day of salt stress indicates that protective mechanisms consists of flavonoid pigments. Therefore, the increase in the anthocyanin content during the long-term stress exposure could be considered as a response to the secondary oxidative stress.

ISSN 1996-4536 (print) • ISSN 2311-0783 (on-line) • Біологічні Студії / Studia Biologica • 2018 • Том 12/№3-4 • С. 27-34 


\section{CONCLUSIONS}

Short term 48-72 h salt shock caused by $100 \mathrm{mM} \mathrm{NaCl}$ led to the increase in TBAactive products, total phenolics concentrations and the decrease in anthocyanins levels. An induction of adaptive responses was revealed by the increase in anthocyanins and restore in phenolic compounds quantity in plant organs under the prolonged (7-days) salt stress.

1. Bourgou S., Bettaieb I., Hamrouni I., Marzouk B. Effect of $\mathrm{NaCl}$ on fatty acids, phenolics and antioxidant activity of Nigella sativa organs. Acta Physiol. Plant, 2012; 34(1): 379-386.

[DOI: https://doi.org/10.1007/s11738-011-0836-3]

2. Chawla S., Jain S., Jain V. Salinity induced oxidative stress and antioxidant system in salttolerant and salt-sensitive cultivars of rice (Oryza sativa L.). J. Plant Biochem. Biotechnol, 2013; 22(1): 27-34.

[DOI: https://doi.org/doi: 10.1007/s13562-012-0107-4]

3. Derkach I.V., Romanyuk N.D. Effect of $\mathrm{NaCl}$ salinity on growth and pigment system of Fagopyrum esculentum Moench. and Vicia faba L. J. V. N. Karazin Khar. Nat. Univ, 2015; 25 : 308-319. (In Ukrainian).

[Google Schollar]

4. Ecophysiology and Responses of Plants under Salt Stress Ed. Parvaiz Ahmad, M.M. Azooz, M.N.V. Prasad Springer Science and Business Media, LCC. 2012

5. Holasova M., Fiedlerova V., Smrcinova H. et al. Buckwheat - The source of antioxidant activity in functional foods. Food Research International, 2002; 35, 207-211.

[DOI: https://doi.org/10.1016/S0963-9969(01)00185-5]

6. Inglett G.E., Rose D.J., Chen D. et al. Phenolic content and antioxidant activity of extracts from whole buckwheat (Fagopyrum esculentum Möench) with or without microwave irradiation. Food Chem, 2010; 119(3): 1216-1219.

[DOI: https://doi.org/10.1016/j.foodchem.2009.07.041]

7. Jaleel C.A., Wang G., Ahmad P., Ikram-ul-Haq. Changes in the photosynthetic characteristics of Catharanthus roseus L. as a result of exogenous growth regulators. Plant Omics J, 2009; 2(4): 169-174.

[Google Schollar]

8. Jindal N., Saxena D.C. Effect of Dehulling on Antioxidant Activity and Total Phenolic Content of Buckwheat (Fagopyrum esculentum) Flour. Asian J. Chem, 2016; 28(7): 1551-1556. [DOI: https://doi.org/10.1016/j.foodchem.2005.08.007]

9. Jovanović Ž.S., Maksimović V.R., Radović S.R. Biochemical and molecular changes in buckwheat leaves during exposure to salt stress. Arch. Biol. Sci, 2011; 63(1): 67-77. [Google Schollar]

10. Kang S., Khan L.A., Waqas M. et al. Plant growth-promoting rhizobacteria reduce adverse effects of salinity and osmotic stress by regulating phytohormones and antioxidants in Cucumis sativus. J. Plant Interact, 2014; 9(1): 673-682. [DOI: https://doi.org/10.1080/17429145.2014.894587

11. Kim H.J., Fonseka J.M., Choi J.H. et al. Salt in irrigation water affects the nutritional and visual properties of romaine lettuce (Lactuca sativa L.). J. Agric Food Chem, 2008; 56(10):3772-6. [PMID: 18439016]; [DOI: https://doi.org/10.1021/jf0733719]

12. Kim S.J., Zaidul I.S., Suzuki T., Mukasa Y., Hashimoto N., Takigawa S., Noda T., MatsuuraEndo C., Yamauchi H. Comparison of phenolic compositions between common and tartary buckwheat sprouts (Fagopyrum). Food Chem, 2008: 110(4); 814-820. [PMID: 26047265]; [DOI: https://doi.org/10.1016/j.foodchem.2008.02.050

13. Kreft I., Vombergar B., Pongrac P. et al. Coordinated buckwheat research: genetics, environment, structure and function. The $13^{\text {th }}$ Int. Symp. on Buckwheat (ISB). Korea. 9-11. 09. 2016; 29-37.

ISSN 1996-4536 (print) • ISSN 2311-0783 (on-line) • Біологічні Студії / Studia Biologica • 2018 • Том 12/№3-4 • С. 27-34 
14. Lim J.H., Park K. J., Kim B. K., Jeong J.W., Kim H.J. Effect of salinity stress on phenolic compounds and carotenoids in buckwheat (Fagopyrum esculentum M.) sprout. Food Chem. 2012; 135(3): 1065-1070.

[PMID: 22953825]; [DOI: https://doi.org/10.1016/j.foodchem.2012.05.068]

15. Lu Q.-H., Wang Y.-Q., Song J.-N., \& Yang H.-B. Transcriptomic identification of salt-related genes and de novo assembly in common buckwheat (F. esculentum ). Plant Physiology and Biochemistry, 2018, 127: 299-309.

[DOI: https://doi.org/10.1016/j.plaphy.2018.02.001]

16. Meena S., Datta S. Peroxidase activity and lipid peroxidation in food legumes Vigna mungo (L.) Hepper and Vigna aconitifolia (Jacq.) Marechal seedlings under salt stress. IJRSR. 2016; 7(2): 8870-8873.

17. Morishita T., Yamaguchi H., Degi K. The Contribution of Polyphenols To Antioxidative Activity in Common Buckwheat and Tartary Buckwheat Grain. Plant Production Science, 2007; 10(1): 99-104.

[DOI: https://doi.org/10.1626/pps.10.99]

18. Musiyenko M.M., Parshykova T.V., Slavnyi P.C. Spectrophotometric methods in practice, physiology, biochemistry and ecology of plants. Kyiv: Fitosociotsentr, 2001. 199 p. (In Ukrainian).

19. Nam T.-G., Lee S.M., Park J.-H., Kim D.-O., Baek N.-in, Eom S.H. Flavonoid analysis of buckwheat sprouts. Food Chemistry, 2015; 170: 97-101.

[DOI: https://doi.org/10.1016/j.foodchem.2014.08.067]

20. Paudel K. R., Kim D.-W. Anti-oxidant and anti-inflammatory activities of Fagopyrum tataricum sprout extracts. The $13^{\text {th }}$ Int. Symposium on Buckwheat (ISB). Korea. 9-11.09.2016; 509-518.

21. Rezazadeh A., Ghasemnezhad A., Barani M., Telmadarrehei T. Effect of Salinity on Phenolic Composition and Antioxidant Activity of Artichoke (Cynara scolymus L.) Leaves Research. J. of Med. Plants, 2012; 6: 245-252.

22. Silveira J.A.G., Carvalho F.E.L. Proteomics, photosynthesis and salt resistance in crops: An integrative view. J. Proteomics, 2016; 143(30): 24-35.

[PMID: 26957143]; [DOI: https://doi.org/10.1016/j.jprot.2016.03.013]

23. Sytar O., Borankulova A., Rauh C., Smetanska I. Effect of chlorocholine chlorid on phenolic acids accumulation and polyphenols formation of buckwheat plants. Biol Res, 2014; 47(1): 19. [PMID: 25027783]; [PMCID: PMC4101719]; [DOI: https://doi.org/10.1186/0717-6287-47-19]

24. Taibi K., Taibi F., Abderrahim L.A., Ennajah A., Belkhodja M., Mulet J.S. Effect of salt stress on growth, chlorophyll content, lipid peroxidation and antioxidant defense systems in Phaseolus vulgaris L. Afr. J. Bot, 2016; 105: 306-312.

25. Watanabe M., Ohshita Y., Tsushida T. Antioxidant Compounds from Buckwheat (Fagopyrum esculentum Möench) Hulls. J. of Agric. and Food Chem, 1997; 45(4): 1039-1044. [DOI: https://doi.org/10.1021/jf9605557]

26. Wei-Yan Z., Gong-Ke Z., Hong-Bing Y. Na+ localization and re-transportation of buckwheat seedlings Afr. J. Agric. Res, 2011; 6(27): 5835-5840.

27. Winkel-Shirley B. Biosynthesis of flavonoids and effects of stress. Curr Opin Plant Biol, 2002; 5: 218-223.

[PMID: 11960739]

28. Zheng L., Meng Y., Ma J., Zhao X., Cheng T., Ji J., Chang E., Meng C., Deng N., Chen L., Shi S., Jiang Z. Transcriptomic analysis reveals importance of ROS and phytohormones in response to short-term salinity stress in Populus tomentosa. Front. Plant Sci, 2015; 6. [DOI: https://doi.org/10.3389/fpls.2015.00678]

29. Zhu F. Chemical composition and health effects of Tartary buckwheat. Food Chemistry, 2016; 203: 231-245.

[DOI: https://doi.org/10.1016/j.foodchem.2016.02.050]

ISSN 1996-4536 (print) • ISSN 2311-0783 (on-line) • Біологічні Студії / Studia Biologica • 2018 • Том 12/№3-4 • С. 27-34 


\title{
ПРОДУКТИ ПЕРЕКИСНОГО ОКИСНЕННЯ ЛІПІДІВ, ФЕНОЛЬНІ СПОЛУКИ Й АНТОЦІАНИ У РОСЛИНАХ ГРЕЧКИ ЗА ДІЇ $\mathrm{NaCI}$
}

\author{
І. В. Деркач ${ }^{\star 1}$, С. Тіммуск², Н. Д. Романюк \\ ${ }^{1}$ Львівський національний університет імені Івана Франка \\ вул. Грушевського, 4, Львів 79005, Україна \\ ${ }^{2}$ Упсальський Біоцентр, Шведський аграрний університет \\ Вох 7026, SE-75007, Упсала, Швеція \\ *e-mail: ari9456@gmail.com
}

\begin{abstract}
Висока концентрація солі у ґрунтовому розчині спричиняє осмотичний та іонний стреси, вторинний окислювальний стрес, пригнічення росту й розвитку рослин і, як наслідок, зниження врожайності важливих сільськогосподарських культур. Гречка (Fagopyrum esculentum Moench.) належить до групи солечутливих рослин-глікофітів, але здатність витримувати засолення у цієї культури вища порівняно з багатьма іншими культурами. Вплив засолення на загальний вміст фенольних сполук, антоціанів і ТБК-активних продуктів як показника перекисного окиснення ліпідів у рослинах гречки (с. Українка) визначали на 48, 72 год (сольовий шок), через 7 діб (сольовий стрес) впливу $\mathrm{NaCl}$. Рослини вирощували на $1 / 2$ поживному середовищі Хогланда-Арнона з/без додавання 100 мM NaCl. Максимальний рівень перекисного окислення ліпідів мембран виявляли через 72 год дії солі: вміст ТБК-активних продуктів зростав у надземній частині (відповідно 130 і 204 \% на листках і стеблах). За 7-добового сольового стресу концентрація ТБК-активних продуктів знижувалася порівняно з контролем у листках і коренях, залишаючись на високому рівні у стеблах. Загальний вміст фенольних сполук був значно вищим у наземних частинах рослин. Концентрація фенолів у коренях за обробки $\mathrm{NaCl}$ на різних часових точках експерименту була в межах від 35,55 до 64,95 мкг/г сухої речовини, у листках - від 98,36 до 112,49 мкг/г сухої речовини. У стеблах сума фенольних сполук була на рівні 80,71-108,32 мкг/г сухої речовини. Через 48 год впливу $\mathrm{NaCl}$ загальний вміст фенолів знизився на 51 та 26 \% у коренях і листках, відповідно. Ця тенденція зберігалася і на 3-тю добу експерименту. На 7-му добу дії солі загальний вміст френольних сполук у коренях наближався до контрольних значень, у листках він залишався достовірно нижчим, ніж у контролі. Зростання вмісту антоціанів у листках і стеблах гречки під час довготривалого впливу стресу узгоджувалося з їхньою антиоксидантною здатністю. Загалом короткочасний сольовий шок несприятливо позначився на фрізіологічній активності рослин гречки. Поступове зниження вмісту ТБК-активних продуктів, відновлення до контрольного рівня загальної кількості фенольних сполук і зростання вмісту антоціанів за тривалішого сольового стресу свідчать про індукцію адаптивних реакцій у досліджуваних рослин.
\end{abstract}

Ключові слова: гречка, $\mathrm{NaCl}$, фенольні сполуки, антоціани, ТБК-активні продукти

Одержано: 23.02.2018

ISSN 1996-4536 (print) • ISSN 2311-0783 (on-line) • Біологічні Студії / Studia Biologica • 2018 • Том 12/№3-4 • С. 27-34 